\title{
PERAN KETUA MAHKAMAH KONSTITUSI DALAM MEMENGARUHI PUTUSAN MAHKAMAH KONSTITUSI
}

\author{
Ali Marwan HSB \\ Kantor Wilayah Kementerian Hukum dan Hak Asasi Manusia Sumatera Utara \\ J1. Putri Hijau No. 4 Medan \\ E-mail : ali_marwan@rocketmail.com dan ali.marwan13@gmail.com \\ Naskah diterima: 8/05/2019, Direvisi: 15/06/2019, Disetujui: 19/06/2019
}

\begin{abstract}
The mistrust of justice seekers to apply for judicial review of the law to the Constitutional Court is certainly a problem in the process of seeking justice in Indonesia. Just because the Chief Justice of the Constitutional Court allegedly lobbied with Commission III of the House of Representatives, then considered the Constitutional Court is no longer objective in deciding a case. In this paper will be seen how the actual existence or role of a Chief Justice of the Constitutional Court in influencing the decision of the Constitutional Court. In the decisionmaking process at the Consultative Assembly of the Judge, the Chief Justice cannot dictate and impose the content of the decision as he or she wishes to all other constitutional judges. This is clearly evident in some decisions of the Constitutional Court, as a Chief Justice of the Constitutional Court lost the debate at the Consultative Assembly of the Judge and filed a dissenting opinion. It can also be seen that a Chief Justice of the Constitutional Court can not influence the decision of the Constitutional Court by his or her position, but by his or her argument against a case. Therefore, to avoid allegations of lobbying between constitutional judges including the Chief Justice of the Constitutional Court and the proposed state institutions, it is suggested that the process of extending the term of constitutional justice is no longer fit and proper test.
\end{abstract}

Keyword: Role, Chief Justice, Constitutional Court, Decision.

\begin{abstract}
Abstrak
Ketidakpercayaan pencari keadilan untuk mengajukan permohonan pengujian undang-undang ke Mahkamah Konstitusi tentu menjadi satu masalah dalam proses pencarian keadilan di Indonesia. Hanya dikarenakan Ketua Mahkamah Konstitusi diduga melakukan lobi-lobi dengan Komisi III Dewan Perwakilan Rakyat, kemudian dianggap Mahkamah Konstitusi tidak lagi objektif dalam memutuskan suatu perkara. Dalam tulisan ini kemudian akan dilihat bagaimana sebenarnya keberadaan atau peran Ketua Mahkamah Konstitusi dalam memengaruhi putusan Mahkamah Konstitusi. Dalam proses pengambilan keputusan pada Rapat Permusyawaratan Hakim, Ketua tidak dapat mendikte dan memaksakan isi putusan sebagaimana yang diinginkannya kepada hakim konstitusi lain. Hal ini jelas terlihat dalam beberapa putusan Mahkamah Konstitusi, dimana seorang Ketua Mahkamah Konstitusi kalah dalam perdebatan dalam Rapat Permusyawaratan Hakim dan mengajukan dissenting opinion. Dari hal tersebut juga dapat dilihat bahwa Ketua Mahkamah Konstitusi tidak bisa memengaruhi putusan Mahkamah Konstitusi dengan kedudukannya, melainkan dengan argumentasinya terhadap suatu perkara. Oleh karena itu, untuk menghindari adanya dugaan-dugaan lobi antara hakim konstitusi termasuk Ketua Mahkamah Konstitusi dengan lembaga negara pengusul disarankan agar proses perpanjangan masa jabatan hakim konstitusi tidak lagi dilakukan fit and proper test.
\end{abstract}

Kata Kunci: Peran, Ketua, Mahkamah Konstitusi, Putusan. 


\section{A. Pendahuluan}

\section{A.1 Latar Belakang}

Eksistensi Mahkamah Konstitusi memiliki arti penting dan peran strategis dalam perkembangan ketatanegaraan dewasa ini. Mahkamah Konstitusi sebagai institusi peradilan memberikan harapan munculnya kekuatan penyeimbang yang dapat menegaskan atau meniadakan kebijakankebijakan yang tidak senyawa dengan konstitusi. Dengan kewenangan yang dilimpahkan UndangUndang Dasar Negara Republik Indonesia Tahun 1945, Mahkamah Konstitusi akan menampung keluhan, permohonan, dan ketidaksetujuan rakyat dalam forum yang bebas dan merdeka, yang akan memutus secara final dan mengikat pada tingkat pertama dan terakhir. Jika Mahkamah Konstitusi setuju dan menyatakan undang-undang tertentu inkonstitusional karena melanggar batas kekuasaan pemerintah yang digariskan dalam konstitusi atau melanggar prinsip-prinsip dasar, baik yang bersifat hak-hak asasi manusia maupun keadilan yang diatur dalam konstitusi, undang-undang tersebut tidak sah dan tidak mempunyai kekuatan hukum yang mengikat. ${ }^{1}$

Eksistensi Mahkamah Konstitusi tersebut kemudian dipertanyakan dengan kasus yang melibatkan Ketua Mahkamah Konstitusi Arief Hidayat. Di mana, Arief Hidayat diduga melakukan lobi-lobi dengan Komisi III Dewan Perwakilan Rakyat terkait dengan perpanjangan masa jabatannya sebagai Hakim Konstitusi.

Ketidakpercayaan terhadap Mahkamah Konstitusi ditandai dengan 2 (dua) indikasi, yaitu: Pertama, dilakukannya pencabutan permohonan Nomor 47/PUU-XV/2017 yang dilakukan oleh pemohon, yaitu: Dr. Busyro Muqoddas, Yayasan Lembaga Bantuan Hukum Indonesia, Konfederasi Persatuan Buruh Indonesia dan Indonesia Corruption Watch pada tanggal 7 Desember 2017. Diperoleh dari berita di media, bahwa alasan pencabutan permohonan yang diajukan oleh para pemohon, yaitu: Pertama, pengakuan Arief Hidayat (Ketua Mahkamah Konstitusi) soal pertemuannya dengan Ketua Komisi III Bambang Soesatyo, Kedua, adanya pemberitaan di beberapa media massa yang menyebut dugaan lobilobi antara Arief dengan sejumlah fraksi agar Arief kembali terpilih sebagai hakim konstitusi dengan janji akan menolak permohonan uji materi hak angket Komisi Pemberantasan Korupsi, dan Ketiga, adanya pelanggaran kode etik hakim konstitusi yang dilakukan oleh Arief Hidayat karena telah bertemu dengan pihak Dewan Perwakilan Rakyat. Menurut Busyro Muqoddas, pertemuan antara Arief Hidayat dengan Komisi III Dewan Perwakilan Rakyat tersebut juga berpotensi memengaruhi putusan perkara yang sedang ditangani Mahkamah Konstitusi. ${ }^{2}$

Indikasi yang Kedua, juga berkaitan juga dengan isu lobi-lobi antara Ketua Mahkamah Konstitusi dengan Komisi III Dewan Perwakilan Rakyat, Indonesia Corruption Watch juga tidak mau mengajukan permohonan pengujian atas UndangUndang tentang Perubahan atas Undang-Undang tentang Majelis Permusyawaratan Rakyat, Dewan Perwakilan Rakyat, Dewan Perwakilan Daerah dan Dewan Perwakilan Rakyat Daerah. Alasannya juga sama yaitu menganggap bahwa Mahkamah Konstitusi tidak lagi objektif karena Ketua Mahkamah Konstitusi Arief Hidayat diduga melakukan lobi-lobi dengan Komisi III terkait dengan perpanjangan masa jabatannya sebagai Hakim Konstitusi. ${ }^{3}$

\section{A.2. Rumusan Masalah}

Pencabutan permohonan dan keengganan untuk mengajukan permohonan pengujian undangundang ke Mahkamah Konstitusi tentu menjadi satu masalah dalam proses pencarian keadilan. Sehingga fenomena ini harus segera diselesaikan agar tidak menjadi contoh bagi pencari keadilan yang lain. Melihat fenomena terakhir ini, dalam tulisan akan

1. Bachtiar, Problematika Implementasi Putusan Mahkamah Konstitusi pada Pengujian UU terhadap UUD, Raih Asa Sukses, Jakarta, 2015, hlm. $229-230$.

2. http://nasional.kompas.com/read/2017/12/14/18233891/mk-kabulkan-penarikan-permohonan-uji-materiterkait-hak-angket-kpk, diakses pada 13 Februari 2018, Pukul 10.00 WIB.

3. https://news.detik.com/berita/3864092/icw-selama-ketua-mk-masih-arief-hidayat-kami-tak-akan-gugat-uumd3, diakses pada 13 Februari 2018, Pukul 10.10 WIB. 
dilihat bagaimana sebenarnya keberadaan atau peran seorang Ketua Mahkamah Konstitusi dalam memengaruhi putusan suatu perkara di Mahkamah Konstitusi.

\section{A.3. Metode Penelitian}

Metode yang digunakan dalam tulisan ini adalah metode penelitian yuridis normatif atau penelitian hukum kepustakaan yaitu metode atau cara yang digunakan di dalam penelitian hukum yang dilakukan dengan cara meneliti bahan pustaka yang ada. ${ }^{4}$ Adapun sifat penelitian yang dipergunakan dalam tulisan ini adalah preskriptif, berpegang pada karakteristik ilmu hukum sebagai ilmu terapan, preskripsi yang diberikan di dalam kegiatan penelitian hukum harus dapat dan mungkin untuk diterapkan. Oleh karena itu yang dihasilkan oleh penelitian hukum, sekalipun bukan asas hukum yang baru atau teori baru, paling tidak argumentasi baru. ${ }^{5}$ (Marzuki, 2011: 251).

\section{B. Pembahasan}

\section{B.1. Mahkamah Konstitusi Dalam Sistem Keta- tanegaraan Indonesia}

Salah satu lembaga baru yang merupakan pengejawantahan amanat konstitusi adalah lahirnya Mahkamah Konstitusi. Lembaran sejarah pertama salah satu cabang kekuasaan kehakiman tersebut, dibuka dengan disetujuinya pembentukan Mahkamah Konstitusi dalam amandemen Ketiga Undang-Undang Dasar Negara Republik Indonesia Tahun 1945 (UUD NRI Tahun 1945) oleh Majelis Permusyawaratan Rakyat pada tahun 2001 sebagaimana dirumuskan dalam ketentuan Pasal 24 ayat (2) dan Pasal 24C Undang-Undang Dasar Negara Republik Indonesia Tahun 1945 yang disahkan pada tanggal November $2001 .^{6}$
Pembentukan Mahkamah Konstitusi merupakan fenomena baru dalam dunia ketatanegaraan. Gagasan pembentukan Mahkamah Konstitusi dinilai cukup populer di negara-negara yang tengah mengalami perubahan dari otoritarian menuju demokrasi. Bahkan menjadi sesuatu yang urgen karena ingin mengubah atau memperbaiki sistem kehidupan ketatanegaraan lebih ideal dan sempurna, khususnya dalam penyelenggaraan pengujian konstitusional terhadap undang-undang yang bertentangan dengan konstitusi sebagai hukum tertinggi negara. ${ }^{7}$

Pembentukan Mahkamah Konstitusi Republik Indonesia dapat dipahami dari dua sisi, yaitu dari sisi politik dan dari sisi hukum. Dari sisi politik ketatanegaraan, keberadaan Mahkamah Konstitusi diperlukan guna mengimbangi kekuasaan pembentukan undang-undang yang dimiliki oleh Dewan Perwakilan Rakyat dan Presiden. Hal itu diperlukan agar undang-undang tidak menjadi legitimasi bagi tirani mayoritas wakil rakyat di Dewan Perwakilan Rakyat dan Presiden yang dipilih langsung oleh mayoritas rakyat. Dari sisi hukum, keberadaan Mahkamah Konstitusi adalah salah satu konsekuensi perubahan dari supremasi Majelis Permusyawaratan Rakyat menjadi supremasi konstitusi, prinsip negara kesatuan, prinsip demokrasi dan prinsip negara hukum. ${ }^{8}$

Ada beberapa alasan mengapa Mahkamah Konstitusi ditempatkan dalam konstitusi yang menjadi dasar konstitusionalitas keberadaannya sebagai salah satu lembaga negara dalam sistem ketatanegaraan Indonesia, yaitu: ${ }^{9}$

1. Pada prinsipnya, konstitusi harus memuat tentang nilai-nilai hak asasi manusia dan perubahan Undang-Undang Dasar Negara Republik Indonesia Tahun 1945 telah mengakomodir lebih jelas dan rinci pasal-pasal yang mengatur hak asasi manusia. Oleh karena itu, lembaga

4. Soerjono Soekanto dan Sri Mamudji, Penelitian Hukum Normatif; Suatu Tinjauan Singkat, Jakarta: Raja Grafindo Persada, 2009, hlm. $13-14$

5. Peter Mahmud Marzuki, Penelitian Hukum, Jakarta: Prenadamedia, 2011, hlm. 251.

6. Soimin dan Mashuriyanto, Mahkamah Konstitusi dalam Sistem Ketatanegaraan Indonesia, Yogyakarta: UII Press, 2013, hlm. 50.

7. Bachtiar, Problematika Implementasi..., Op. Cit., hlm. 74.

8. Tim Penyusun, Hukum Acara Mahkamah Konstitusi, Jakarta: Sekretariat Jenderal dan Kepaniteraan MKRI, 2010, hlm. 7 .

9. KRHN, Menggapai Keadilan Konstitusi; Suatu Rekomendasi untuk Revisi UU Mahkamah Konstitusi, Jakarta: KRHN-USAID-DRSP, 2008, hlm. 12 - 13. 
yang berwenang menjamin, melindungi dan menegakkan nilai-nilai hak asasi manusia itu harus pula diletakkan dalam konstitusi;

2. Konstitusi pada prinsipnya harus memberikan pembatasan kekuasaan dan menyediakan mekanisme checks and balances antara cabang kekuasaan. Adanya Mahkamah Konstitusi beserta kewenangannya menunjukkan bahwa perubahan konstitusi sudah memuat adanya pembatasan kekuasaan dan mekanisme checks and balances tersebut;

3. Keberadaan Mahkamah Konstitusi berikut dengan kewenangan dalam konstitusi, sejalan dan merupakan penegasan terhadap prinsip negara hukum yang telah dimuat dalam perubahan konstitusi. Ini karena ciri-ciri dari negara hukum dapat ditunjukkan dari adanya wewenang untuk menguji konstitusionalitas undang-undang oleh kekuasaan kehakiman;

4. Konstitusi sebagai hukum tertinggi harus ditegakkan dan dijalankan secara konsisten oleh siapa pun. Oleh karena itu, konstitusi harus pula menyediakan lembaga yang berwenang untuk menjaga nilai-nilai konstitusi, yang mesti ditempatkan di dalam konstitusi

Menurut Bambang Widjojanto, gagasan pembentukan Mahkamah Konstitusi di dalam sistem ketatanegaraan di Indonesia didasarkan pada tiga gagasan utama, yaitu: ${ }^{10}$

1. Tidak adanya mekanisme ketatanegaraan untuk menyelesaikan sengketa kewenangan antarlembaga tinggi negara;

2. Ketiadaan prosedur untuk mengatasi tafsir ganda terhadap konstitusi dan/atau memberi interpretasi pada konstitusi agar dilaksanakan secara bertanggungjawab sesuai dengan kehendak rakyat dan cita-cita demokrasi;

3. Munculnya kebutuhan konstitusional untuk membangun dan melaksanakan prinsip checks and balances di dalam sistem ketatanegaraan ke depan.

Pembentukan Mahkamah Konstitusi dalam sistem ketatanegaraan Indonesia berpijak pada 4 (empat) pilar fundamental yakni: Pertama, sebagai paham konstitusionalitas yang pada hakekatnya ingin menciptakan terselenggaranya pembatasan kekuasaan secara berimbang oleh penyelenggara negara agar tidak sewenang-wenang, Kedua, sebagai instrumen check and balance sehingga tercipta saling kontrol. Oleh karena itu kehadiran Mahkamah Konstitusi sebagai bagian dari kekuasaan kehakiman sangat dibutuhkan dalam mewujudkan pelaksanaan check and balance agar tidak terjadi overlapping dalam pelaksanaan kekuasaan negara yang diamanatkan oleh Undang-Undang Dasar Tahun 1945, Ketiga, menciptakan penyelenggaraan negara yang bersih sehingga penyelenggara negara harus memiliki kepekaan terhadap kepentingan rakyat dengan menaati asas-asas penyelenggaraan negara yang baik dan bersih, dan Keempat, perlindungan terhadap hak asasi manusia karena kekuasaan yang tidak tersentuh oleh mekanisme kontrol sangat potensial melakukan tindakan sewenang-wenang, oleh karena itu dengan kehadiran Mahkamah Konstitusi diharapkan melakukan pengawasan secara mandiri dan objektif terhadap pada penyelenggara negara agar tetap berpijak pada perlindungan dan penghormatan terhadap hak asasi manusia dan prinsip-prinsip demokrasi. ${ }^{11}$

Berdasarkan beberapa pendapat tersebut, dapat dikatakan bahwa keberadaan Mahkamah Konstitusi itu sendiri sesungguhnya memberikan suatu harapan akan tegaknya konstitusi dalam kerangka negara hukum, karena hak menguji yang menjadi kewenangan Mahkamah Konstitusi itu merupakan pranata yang berkaitan erat dengan konsep hukum dasar dan tertinggi. Dari sudut pandang ini, keberadaan Mahkamah Konstitusi di Indonesia adalah melindungi konstitusi dari pelanggaran atau penyimpangan yang mungkin dilakukan dari badan pembuat undang-undang. ${ }^{12}$

Kewenangan yang diberikan kepada menempatkan Mahkamah Konstitusi sebagai salah satu lembaga negara yang menjalankan 5 (lima)

10. Bambang Widjojanto, Kajian Yuridis Putusan Mahkamah Konstitusi 2009, Jakarta: Kemitraan Partnership, 2009, hlm. $4-5$.

11. Tim KRHN, Pokok-Pokok Pikiran dan RUU Mahkamah Konstitusi, Jakarta: KRHN dan Kemitraan, 2003, hlm. 3 - 4.

12. Bachtiar, Problematika Implementasi..., Op. Cit., hlm. 88 - 89. 
fungsi. Fungsi pertama adalah sebagai pengawal konstitusi (the guardian of the constitution) Fungsi ini sesuai dengan latar belakang keberadaan Mahkamah Konstitusi untuk menjamin pelaksanaan dan penegakan konstitusi dalam penyelenggaraan negara Fungsi ini mewujud dalam kewenangan Mahkamah Konstitusi memutus perkara-perkara penting dan mendasar yang terkait dengan isu konstitusi. ${ }^{13}$

Fungsi kedua adalah sebagai penafsir akhir konstitusi (the final interpreter of the constitutioni). Fungsi ini berkaitan erat dengan kewenangan menguji undang-undang terhadap undang-undang dasar, di mana Mahkamah Konstitusi harus memutuskan bagaimana seharusnya undang-undang dasar ditafsirkan ke dalam undang-undang ${ }^{14}$ Fungsi ketiga adalah sebagai pelindung hak konstitusional warga negara (the protector of citizen's constitutional rights). Fungsi ini berkaitan dengan materi muatan konstitusi yaitu memberikan jaminan terhadap hak konstitusional warga negara. Oleh karena itu, Mahkamah Konstitusi harus membatalkan ketentuan undang-undang yang jelas-jelas melanggar hak konstitusional warga negara yang diatur di dalam undang-undang dasar. Dan ini berkaitan erat juga dengan fungsi keempat Mahkamah Konstitusi yaitu sebagai pelindung hak asasi manusia. ${ }^{15}$

Fungsi kelima adalah sebagai pengawal demokrasi (the guardian of democracy). Fungsi mengawal demokrasi melekat pada wewenang memutus pengujian undang-undang, di mana wewenang pengujian undang-undang menjadi instrumen hukum untuk memastikan bahwa setiap proses pembentukan undang-undang dan materinya sesuai dengan prinsip-prinsip demokrasi. ${ }^{16}$

\section{B.2 Proses Pengangkatan Hakim Konstitusi}

Cara pengisian Hakim Konstitusi memiliki cara yang unik, karena dari 9 (sembilan) hakim konstitusi diisi atas pilihan dari 3 (tiga) lembaga negara yang menggambar trias politica, yaitu Presiden, Dewan Perwakilan Rakyat dan Mahkamah Agung. Hal tersebut diatur dalam Pasal 24C ayat (3) Undang-
Undang Dasar Negara Republik Indonesia Tahun 1945 yang menyatakan bahwa "Mahkamah Konstitusi mempunyai sembilan orang anggota hakim konstitusi yang ditetapkan oleh Presiden, yang diajukan masingmasing tiga orang oleh Mahkamah Agung, tiga orang oleh Dewan Perwakilan Rakyat dan tiga orang oleh Presiden".

Dalam Undang-Undang Nomor 24 Tahun 2003 tentang Mahkamah Konstitusi tidak diatur secara jelas bagaimana prosedur pengajuan calon hakim konstitusi tersebut. Mengenai pengangkatan hakim konstitusi diatur mulai pasal 15 sampai pasal 21 dalam suatu bagian tersendiri yang disebut Pengangkatan. Melalui ketentuan tersebut, undangundang ini mengatur konsep pengangkatan hakim konstitusi dalam beberapa segi sebagai derivate pasal 24C ayat 5 dan 6 serta pasal 25 UUD NRI 1945 dan sebagai kesatuan organic bersama pasal 33, 34 dan 35 UU MK. Pertama, terdapat tambahan atas syarat-syarat kualitas diri dan dan administratif calon hakim konstitusi. Kedua, larangan-larangan rangkap jabatan apabila telah menjadi hakim konstitusi. Ketiga, penguatan wewenang DPR, Presidendan Mahkamah Agung dalam pengajuan hakim konstitusi yang dilengkapi jangka waktu bagi Presiden dalam menerbitkan pengesahannya melalui Keputusan Presiden. Keempat, bahwa ketentuan lanjutan mengenai tata cara seleksi, pemilihan, dan pengajuan hakim konstitusi dikuasakan pada masingmasing lembaga Negara yang mengajukan hakim konstitusi yakni DPR, Presiden, dan Mahkamah Agung, dimana pencalonan hakim konstitusi tersebut harus dilakukan secara transparan dan partisipatif serta dengan suatu pemilihan hakim konstitusi yang objektif dan akuntabel. Kelima, mengenai kata sumpah dan janji dalam pengangkatan hakim konstitusi dan ketua/wakil hakim konstitusi yang diikrarkan di hadapan Presiden. Substansi pengaturan mengenai pengangkatan hakim konstitusi tersebut menunjukkan perlu dilakukan suatu kajian konsep-konsep untuk mengetahui pembelokan (refraksi) hukum pengangkatan hakim

13. Janedjri M. Gaffar, Politik Hukum Pemilu, Jakarta: Konstitusi Press, 2012, hlm. 154.

14. Ibid, hlm. 154-155.

15. Ibid, hlm. 155-156.

16. Ibid, hlm. 156 . 
konstitusi. Sehingga dapat diwujudkan suatu prospek pelurusan/pengembalian (alinasi) dalam upaya menyelesaikan diskursus hukum pengangkatan hakim konstitusi tersebut sebagai perwujudan peradilan ketatanegaraan yang berkeadilan di Indonesia. ${ }^{17}$

Pasal 19 Undang-Undang Nomor 24 Tahun 2003 tentang Mahkamah Konstitusi menyebutkan bahwa "Pencalonan hakim konstitusi dilaksanakan secara transparan dan partisipatif". Menurut Andi Mattalata, bahwa bersifat transparan dan aspiratif sesuai dengan Pasal 19 ini yaitu: ${ }^{18}$

1. Transparan;

a. Publikasi ke media massa mengenai proses pengajuan dan penyeleksian hakim konstitusi pada seluruh lembaga negara yang berwenang mengajukan hakim konstitusi;

b. Transparansi mengenai hasil seleksi dan pertimbangan pemilihan hakim konstitusi dari lembaga negara yang berwenang mengajukan hakim konstitusi.

2. Partisipatif;

a. Masyarakat dapat menyaksikan langsung proses seleksi pengajuan hakim konstitusi;

b. Masyarakat dapat memberiksan masukan kepada lembaga yang berwenang mengajukan hakim kontitusi mengenai calon hakim konstitusi yang hendak dicalonkan;

c. Masyarakat dapat mengikuti proses seleksi hakim konstitusi.

Lebih lanjut dalam Pasal 20 Undang-Undang Nomor 24 Tahun 2003 tentang Mahkamah Konstitusi ditegaskan bahwa "ketentuan mengenai tata cara seleksi, pemilihan dan pengajuan hakim konstitusi diatur oleh masing-masing lembaga yang berwenang". Kemudian ditegaskan juga bahwa "pemilihan hakim konstitusi oleh lembaga yang berwenang dilaksanakan secara obyektif dan akuntabel".

Menurut Arief Hidayat, mekanisme seleksi hakim konstitusi akan sangat menentukan figur yang terpilih sebagai hakim konstitusi sehingga akan sangat memengaruhi performa Mahkamah Konstitusi. Selain itu, banyak kalangan menilai: Pertama, seleksi hakim konstitusi selama ini banyak yang tidak memenuhi prinsip yang diamanatkan oleh UU MK; Kedua, model seleksi terbuka melalui panitia seleksi adalah yang paling ideal, karena model seleksi terbuka ini yang dianggap paling memenuhi prasyarat transparansi, partisipatif, objektif, dan akuntabel sesuai dengan amanat UU MK; dan Ketiga, seleksi terbuka hakim konstitusi ini menimbulkan suatu anomali karena Undang-Undang Dasar Negara Republik Indonesia Tahun 1945 menyebutkan dengan tegas bahwa hakim konstitusi harus negarawan sehingga proses seleksi hakim konstitusi juga harus lebih ditinggikan daripada pengisian jabatan lainnya. ${ }^{19}$

Pada praktiknya, tidak ada keseragaman mekanisme pengangkatan hakim konstitusi yang dilakukan oleh Dewan Perwakilan Rakyat, Mahkamah Agung, dan Presiden sebagai lembaga negara pengusul hakim konstitusi. Ada beberapa mekanisme yang selama ini pernah ditempuh yaitu hakim konstitusi dipilih berdasarkan mekanisme penunjukan langsung, pemilihan yang dilakukan oleh tim internal secara tertutup, uji kelayakan dan kepatutan oleh panel ahli yang dibentuk oleh Komisi Yudisial, dan seleksi terbuka yang dilakukan oleh panitia seleksi. ${ }^{20}$ Menurut Pan Mohamad Faiz, agar tidak bertentangan dengan konstitusi, terdapat dua alternatif yang dapat ditempuh oleh lembaga negara pengusul dalam menyempurnakan mekanisme seleksi hakim konstitusi. Pertama, pembentukan panitia seleksi atau panitia ahli yang pernah dilakukan oleh Presiden dan Dewan Perwakilan Rakyat sebaiknya diteruskan menjadi inisiatif dari masing-masing lembaga negara pengusul. Hal ini

17. Mira Fajriyah, "Refraksi dan Alinasi Pengangkatan Hakim Konstitusi”, Jurnal Konstitusi, Volume 12, Nomor 2, Juni 2015, hlm. 240.

18. Bagus Joko Puruitomo dan Fitra Arsil, "Mekanisme Pengangkatan Hakim Konstitusi", Makalah, hlm. 8 - 9, http:// lib.ui.ac.id/naskahringkas/2016-05/S55607-Bagus\%20Joko\%20Puruitomo, diunduh pada 21 Februari 2018 Pukul 09.00 WIB.

19. Shanti Dwi Kartika, "Seleksi untuk Pengangkatan Hakim Konstitusi", Majalah Info Singkat Hukum, Vol. IX, No. 06/ II/Puslit/Maret/2017, hlm. 2.

20. Ibid. 
akan dapat mengurangi kepentingan personal dan subjektivitas keputusan yang dibuat oleh Presiden, Dewan Perwakilan Rakyat, dan Mahkamah Agung; dan Kedua, lembaga negara pengusul dapat juga bekerja sama dengan Komisi Yudisial sebagai panitia seleksi tetapi keputusan akhir untuk menentukan calon hakim konstitusi tetap berada di tangan lembaga negara pengusul. Kerjasama formal ini tidak akan bertentangan dengan Undang-Undang Dasar Negara Republik Indonesia Tahun 1945 karena dilakukan atas inisiatif dari lembaga Negara pengusul, bukan pemberian kewenangan atributif yang bersifat mutlak berdasarkan undang-undang. ${ }^{21}$ Mengenai tata cara seleksi hakim konstitusi, penulis lebih sepakat agar diberikan kepada suatu dewan yang independen yang terdiri dari ahli hukum tata negara, bukan langsung oleh lembaga negara pengusul yaitu Dewan Perwakilan Rakyat, Presiden, dan Mahkamah Agung. ${ }^{22}$ Selain tidak adanya pengaturan yang tegas tentang tata cara pengangkatan hakim konstitusi oleh ketiga lembaga negara pengusul, ketentuan lain yang kosong adalah proses pengangkatan kembali sebagai hakim konstitusi. Karena sebagaimana diatur dalam Pasal 22 yang menyatakan bahwa "masa jabatan hakim konstitusi adalah 5 (lima) tahun dan dapat dipilih kembali hanya untuk satu kali masa jabatan". Hakim konstitusi yang pernah diperpanjang masa jabatannya antara lain: Jimly Asshiddiqie, Abdul Mukhtie Fadjar, Maruarar Siahaan dan Maria Farida Indrati.

Tidak adanya ketentuan yang mengatur tentang proses perpanjangan masa jabatan hakim konstitusi juga menjadi polemik, ketika Ketua Mahkamah Konstitusi, Hamdan Zoelva, akan berakhir masa jabatan. Ketika itu, Hamdan Zoelva menolak ikut fit and proper test calon hakim konstitusi yang dilaksanakan oleh panitia seleksi. Hamdan Zoelva beralasan bahwa tidak ikut fit and proper test karena sedang menjabat sebagai hakim konstitusi dan Ketua Mahkamah Konstitusi yang tentunya sudah memenuhi syarat sebagai hakim konstitusi. Hamdan Zoelva menyerahkan keputusan layak atau tidaknya dirinya menjadi hakim konstitusi lagi kepada panitia seleksi dan Presiden berdasarkan rekam jejak dan kinerjanya sebagai hakim konstitusi dan Ketua Mahkamah Konstitusi selama ini. ${ }^{23}$

Hal ini jugalah yang kemudian menimpa Ketua Mahkamah Konstitusi Arief Hidayat, ketika akan mengakhiri masa jabatannya sebagai hakim konstitusi yang diajukan oleh Dewan Perwakilan Rakyat. Sehingga dianggap pada proses fit and proper test-nya di Komisi III Dewan Perwakilan Rakyat diduga melakukan lobi-lobi agar diangkat kembali menjadi hakim konstitusi.

\section{B.3. Kedudukan Ketua Mahkamah Konstitusi dan Proses Pengisiannya}

Pasal 24C ayat (4) Undang-Undang Dasar Negara Republik Indonesia Tahun 1945 menyebutkan bahwa "Ketua dan Wakil Ketua Mahkamah Konstitusi dipilih dari dan oleh hakim konstitusi". Ketentuan tata cara pemilihan Ketua dan Wakil Ketua Mahkamah Konstitusi tersebut kemudian diatur dalam UndangUndang Nomor 23 Tahun 2004 tentang Mahkamah Konstitusi yang telah diubah dengan UndangUndang Nomor 8 Tahun 2011 tentang Perubahan atas Undang-Undang Nomor 23 Tahun 2004 tentang Mahkamah Konstitusi.

Ketentuan mengenai proses pemilihan Ketua dan Wakil Ketua Mahkamah Konstitusi diatur secara jelas pada Pasal 4 Undang-Undang tentang Mahkamah Konstitusi yang kemudian dirinci lagi ke dalam Peraturan Mahkamah Konstitusi Nomor 3 Tahun 2012 tentang Tata Cara Pemilihan Ketua dan Wakil Ketua Mahkamah Konstitusi. Dalam peraturan tersebut ditegaskan bahwa Ketua dan Wakil Ketua Mahkamah dipilih dari dan oleh hakim untuk masa jabatan 2 (dua) tahun 6 (enam) bulan terhitung sejak tanggal pengangkatan Ketua dan Wakil Ketua Mahkamah. Pengambilan keputusan pemilihan Ketua atau Wakil Ketua Mahkamah dilakukan secara musyawarah mufakat dalam rapat pleno hakim yang tertutup untuk umum. Dalam hal pengambilan keputusan tidak mencapai mufakat,

21. Pan Mohamad Faiz, "Mekanisme Seleksi Hakim Konstitusi", Koran Sindo, Kamis, 2 Februari 2017.

22. Ali Marwan Hsb, "Mahkamah Konstitusi sebagai Neutralizer terhadap Lembaga Politik", Jurnal Rechtsvinding, Volume 2 Nomor 3, Desember 2013, hlm. 329.

23. https://www.jpnn.com/news/hamdan-tolak-ikut-fit-and-proper-test, diakses pada 21 Februari 2018, Pukul 10.00 WIB. 
keputusan diambil berdasarkan suara terbanyak melalui pemungutan suara dalam rapat pleno hakim terbuka untuk umum. Kemudian, Ketua dan Wakil Ketua Mahkamah terpilih mengucapkan sumpah atau janji menurut agamanya di hadapan Mahkamah.

Dalam Undang-Undang Nomor 24 Tahun 2003 tentang Mahkamah Konstitusi dan UndangUndang Nomor 8 Tahun 2011 tentang Perubahan atas Undang-Undang Nomor 24 Tahun 2003 tentang Mahkamah Konstitusi tidak dirincikan secara jelas apa saja tugas dari Ketua Mahkamah Konstitusi. Hanya disebutkan bahwa Hakim Konstitusi adalah pejabat Negara, dan kedudukan protokoler dan hak keuangan Ketua, Wakil Ketua dan anggota hakim konstitusi berlaku peraturan perundang-undangan bagi pejabat negara. Selain itu, dalam hukum acara Mahkamah Konstitusi yang diatur dalam Bab V Pasal 28 ayat (1) yaitu bahwa "Mahkamah Konstitusi memeriksa, mengadili dan memutus dalam sidang pleno Mahkamah Konstitusi dengan 9 (sembilan) orang hakim konstitusi, kecuali dalam keadaan luar biasa dengan 7 (tujuh) orang hakim konstitusi yang dipimpin oleh Ketua Mahkamah Konstitusi.

Walaupun demikian, tugas dan fungsi Ketua Mahkamah Konstitusi dapat kita lihat dari pendapat yang disampaikan oleh mantan Ketua Mahkamah Konstitusi, yaitu Jimly Asshiddiqie dan Moh. Mahfud MD. Menurut Jimly Asshiddiqie, Ketua Mahkamah Konstitusi bertindak sebagai ketua persidangan dan juga sebagai penanggung jawab umum administrasi negara di lingkungan Mahkamah Konstitusi. ${ }^{24} \mathrm{Hal}$ senada juga disebutkan oleh Moh. Mahfud MD, bahwa Ketua Mahkamah Konstitusi adalah orang nomor satu sebagai pejabat negara di Mahkamah Konstitusi. ${ }^{25}$

\section{B.4. Keberadaan Ketua Mahkamah Konstitusi Dalam Proses Pengambilan Keputusan}

Proses pengambilan keputusan dalam perkara di Mahkamah Konstitusi diatur dalam UU MK dan Peraturan Mahkamah Konstitusi Nomor 2 Tahun
2012 tentang Persidangan Mahkamah Konstitusi. Dalam rangka mengambil putusan, setiap Hakim Konstitusi wajib menyampaikan pertimbangan atau pendapat tertulis terhadap permohonan. Putusan diambil dalam Rapat Permusyawaratan Hakim yang dihadiri sekurang-kurangnya 7 (orang) Hakim Konstitusi. Pengambilan keputusan dilakukan dengan cara musyawarah untuk mufakat. Dalam hal musyawarah tidak mencapai mufakat, maka pengambilan keputusan dilakukan dengan suara terbanyak. Dalam hal keputusan tidak dapat diambil dengan suara terbanyak, maka suara terakhir Ketua Mahkamah menentukan.

Putusan Mahkamah Konstitusi yang diambil secara mufakat oleh 9 (sembilan) hakim konstitusi tanpa perbedaan pendapat memiliki kekuatan yang sama, tidak kurang dan tidak lebih, dengan putusan Mahkamah Konstitusi yang diambil dengan suara terbanyak dengan komposis 5 (lima) berbanding 4 (empat). ${ }^{26}$

Jika kemudian proses pengambilan keputusan tersebut diperhatikan, Ketua Mahkamah Konstitusi tidak dapat memengaruhi putusan hakim konstitusi lain. Karena seorang Ketua Mahkamah Konstitusi menyampaikan pandangan terhadap suatu perkara setelah seluruh hakim konstitusi menyampaikan pendapatnya. Apalagi proses pengambilan keputusan dilakukan secara musyawarah mufakat, Ketua Mahkamah Konstitusi hanya dapat memengaruhi pendapat hakim konstitusi lain jika pendapat tersebut sesuai dengan pendapat hakim konstitusi lainnya, karena seorang hakim konstitusi harus memiliki integritas. Kemudian dalam pengambilan keputusan secara voting, seorang Ketua Mahkamah Konstitusi juga diberikan kesempatan terakhir untuk memberikan suara. Suara seorang Ketua Mahkamah Konstitusi menentukan putusan jika suara hakim lainnya seimbang. Jika 4 (empat) hakim menerima dan 4 (empat) hakim menolak, maka suara Mahkamah Konstitusi akan menjadi putusan mayoritas. Akan

24. Jimly Asshiddiqie, "Kedudukan Mahkamah Konstitusi dalam Struktur Ketatanegaraan Indonesia",http://www. mahkamahkonstitusi.go.id/index.php?page=web.Berita\&id=11779\#.WoMMW7x19dI, diakses pada 14 Februari 2018, Pukul 09.00 WIB.

25. Rita Triana Budiarti, Kontroversi Mahfud MD Jilid 1, Konstitusi Press, Jakarta, 2012, hlm. 21 - 22.

26. Muchammad Ali Safa'at, dkk, Hukum Acara Mahkamah Konstitusi, Sekretariat Jenderal Mahkamah Konstitusi RI, Jakarta, 2011, hlm. 62 . 
tetapi, apabila dalam pengambilan keputusan sudah ada suara mayoritas seperti 5 (lima) berbanding 3 (tiga), maka suara Ketua Mahkamah Konstitusi tidak akan memengaruhi putusan sama sekali.

Tidak bisanya seorang Ketua Mahkamah Konstitusi memengaruhi putusan Mahkamah Konstitusi tentunya dapat dilihat dari beberapa perkara yang sudah diputuskan, bahwa Ketua Mahkamah Konstitusi bisa dikalahkan oleh anggota lainnya dan harus membuat dissenting opinion.

Sebagai contoh kasus, yang cukup menyita perhatian publik, yang menunjukkan bahwa Ketua Mahkamah Konstitusi tidak dapat memengaruhi putusan adalah dalam perkara Nomor 46/PUUXIV/2016 yaitu pengujian atas Undang-Undang Nomor 1 Tahun 1946 tentang Peraturan Hukum Pidana atau Kitab Undang-Undang Hukum Pidana dan pasal yang dimohonkan pengujiannya adalah Pasal 284 ayat (1) sampai dengan ayat (5), Pasal 285, dan Pasal 292. Dalam putusannya berkaitan dengan memperjelas rumusan delik kesusilaan Mahkamah Konstitusi menyatakan menolak permohonan pemohon. Putusan dalam perkara ini diputuskan melalui suara terbanyak dengan perbandingan 5 (lima) berbanding 4 (empat). 5 (lima) orang hakim menyatakan menolak permohonan pemohon dengan argumentasi bahwa Mahkamah Konstitusi hanya menyatakan bahwa norma-norma pasal dalam Kitab Undang-Undang Hukum Pidana yang dimohonkan oleh pemohon tidak bertentangan dengan UndangUndang Dasar Negara Republik Indonesia Tahun 1945. Perihal perlu atau tidaknya dilengkapi, hal itu sepenuhnya merupakan kewenangan pembentuk undang-undang melalui kebijakan pidana-nya yang merupakan bagian dari politik hukum pidana. Sedangkan 4 (orang) hakim mengajukan dissenting opinion dan menyatakan bahwa permohonan pemohon seharusnya dikabulkan dengan alasan bahwa UndangUndang Dasar Negara Republik Indonesia Tahun 1945 tidak boleh membiarkan kebebasan absolut setiap orang untuk berbuat semata-mata menurut kehendaknya, terlebih lagi dalam hal perbuatan tersebut jelas mereduksi, mempersempit, melampaui batas, dan bertentangan dengan nilai agama serta sinar ketuhanan. Oleh karena itu, manakala UndangUndang Dasar Negara Republik Indonesia Tahun 1945 bersinggungan dengan nilai agama, UndangUndang Dasar Negara Republik Indonesia Tahun 1945 sebagai konstitusi yang berketuhanan harus menegaskan jati dirinya sebagai penjamin freedom of religion dan bukan freem from religion sehingga segala kepastian hukum dalam bentuk norma undangundang yang mereduksi, mempersempit, melampaui batas, dan bahkan bertentangan dengan nilai agama serta sinar ketuhanan haruslah dinyatakan bertentangan denganUndang-Undang Dasar Negara Republik Indonesia Tahun 1945 dan tidak mempunyai kekuatan hukum mengikat. Dan salah satu dari 4 (empat) orang hakim yang mengajukan dissenting opinion tersebut adalah Ketua Mahkamah Konstitusi, Arief Hidayat.

Jika seorang Ketua Mahkamah Konstitusi bisa memengaruhi putusan hakim konstitusi yang lain, sudah barang tentu, semua putusan Mahkamah Konstitusi mengikuti keinginan Ketua-nya. Akan tetapi buktinya, bahwa Ketua Mahkamah Konstitusi juga sering kalah ketika beradu argumentasi dengan hakim konstitusi lainnya yang juga merupakan ahli hukum.

Hal ini juga dinyatakan oleh Moh. Mahfud MD ketika menjadi Ketua Mahkamah Konstitusi periode 2008 sampai dengan 2013, bahwa dalam memutus perkara di Mahkamah Konstitusi, hakim konstitusi tidak dapat didikte oleh Ketua Mahkamah Konstitusi. Jadi, Ketua pun tidak dapat memenangkan pendapatnya di depan para hakim konstitusi lain. Ini berarti bahwa, Ketua Mahkamah Konstitusi tidak sewenang-wenang ketika memutus suatu perkara. ${ }^{27}$ Ketika menjadi Ketua Mahkamah Konstitusi, Moh. Mahfud MD juga pernah kalah dalam proses pengambilan keputusan dalam Rapat Permusyawaratan Hakim yaitu dalam perkara Nomor 138/PUU-VII/2009 tentang Pengujian atas Peraturan Pemerintah Pengganti Undang-Undang Nomor 4 Tahun 2009 tentang Perubahan atas Undang-Undang Nomor 30 Tahun 2002 tentang Komisi Pemberantasan Tindak Pidana Korupsi. Dalam putusan perkara ini, memang Mahkamah Konstitusi

27. Rita Triana Budiarti, Kontroversi Mahfud MD Jilid 2 di Balik Putusan Mahkamah Konstitusi, Konstitusi Press, Jakarta, 2013, hlm. $30-31$. 
memutuskan bahwa pemohon tidak memiliki legal standing untuk mengajukan permohonan. Tetapi, yang menarik adalah Mahkamah Konstitusi dalam Putusan ini menyatakan bahwa Mahkamah Konstitusi berwenang untuk menguji peraturan pemerintah pengganti undang-undang. Dalam putusan tersebut memang dicantumkan bahwa Ketua Mahkamah Konstitusi saat itu, Moh. Mahfud MD menyatakan alasan yang berbeda (concuring opinion). Tetapi, jika kita lihat dalam buku Kontroversi Mahfud MD Jilid 2 dibalik Putusan Mahkamah Konstitusi, Mahfud MD menyatakan bahwa dalam proses pengambilan keputusan, Ketua Mahkamah Konstitusi kalah melawan para hakim. Karena menurutnya, Mahkamah Konstitusi tidak berwenang untuk menguji peraturan pemerintah pengganti undangundang karena sudah disebutkan dengan jelas dalam Undang-Undang Dasar Negara Republik Indonesia Tahun 1945 bahwa Mahkamah Konstitusi berwenang untuk menguji undang-undang. ${ }^{28}$

\section{Kesimpulan}

Berdasarkan pembahasan di atas, dapat disimpulkan beberapa hal sebagai berikut:

1. Bahwa belum ada keseragaman proses pengangkatan hakim konstitusi oleh tiga lembaga negara pengusul yaitu Presiden, Dewan Perwakilan Rakyat dan Mahkamah Agung. Demikian juga tentang proses pengangkatan kembali atau perpanjangan masa jabatan hakim konstitusi yang belum ada pengaturan yang tegas. Yang selama ini disamakan dengan proses pengangkatan hakim konstitusi yang baru dengan mengikuti fit and proper test lagi;

2. Bahwa proses pengambilan keputusan dalam Rapat Permusyawaratan Hakim, Ketua Mahkamah Konstitusi mempunyai kedudukan yang sama dengan semua hakim konstitusi untuk memberikan pendapatnya dalam setiap perkara yang ditangani. Untuk memutuskan suatu perkara, cara terakhir yang digunakan adalah voting. Suara Ketua Mahkamah Konstitusi juga sama nilainya dengan suara hakim konstitusi lainnya. Jadi, seorang Ketua Mahkamah Konstitusi tidak bisa memengaruhi semua hakim konstitusi untuk membuat putusan sesuai dengan kemauannya. Hal tersebut dapat dilihat dari berbagai putusan Mahkamah Konstitusi, di mana seorang Ketua Mahkamah Konstitusi berada di pihak yang kalah dalam proses pengambilan keputusan dan memberikan dissenting opinion dan berbeda pendapat dengan kebanyakan hakim lain. Oleh karena itu tidak ada alasan lagi untuk tidak mau mengajukan permohonan pengujian undang-undang ke Mahkamah Konstitusi dengan alasan ketuanya bisa dilobi karena Mahkamah Konstitusi bukan hanya ketuanya saja, melainkan sembilan hakim konstitusi.

Berdasarkan kesimpulan tersebut di atas, dapat diberikan beberapa saran sebagai berikut, bahwa untuk menghindari terjadinya dugaan lobi-lobi sebagaimana yang terjadi kepada Ketua Mahkamah Konstitusi Arief Hidayat, ada baiknya proses perpanjangan masa jabatan hakim konstitusi tidak perlu lagi diakan fit and proper test karena hakim konstitusi yang sudah menjalani satu kali masa jabatan tentu sudah melewati fit and proper test ketika diajukan menjadi hakim konstitusi oleh 3 (tiga) lembaga yang berwenang yaitu Presiden, Dewan Perwakilan Rakyat, dan Mahkamah Agung. Jika memang keberadaannya sebagai hakim konstitusi dalam satu kali masa jabatan memiliki rekam jejak yang baik, maka langsung saja diberikan perpanjangan masa jabatan. Dengan demikian, dugaan lobi-lobi dari pihak pengusul yang menyebabkan independensi sang hakim tidak diragukan lagi.

Selain itu, terkait dengan perpanjangan masa jabatan hakim konstitusi disarankan agar dilakukan perubahan atas UU MK agar mengakomodir pengaturan mengenai mekanisme perpanjangan masa jabatan hakim konstitusi untuk masa jabatan yang kedua. Dengan catatan bahwa proses perpanjangan masa jabatan hakim konstitusi tidak perlu lagi dilakukan fit and proper test.

28. Ibid. 


\section{Daftar Pustaka}

\section{Buku}

Bachtiar, Problematika Implementasi Putusan Mahkamah Konstitusi pada Pengujian UU terhadap UUD, Jakarta: Raih Asa Sukses, 2015.

Bambang Widjojanto, Kajian Yuridis Putusan Mahkamah Konstitusi 2009, Jakarta: Kemitraan Partnership, 2009.

Janedjri M. Gaffar, Politik Hukum Pemilu, Jakarta: Konstitusi Press, 2012.

KRHN, Menggapai Keadilan Konstitusi; Suatu Rekomendasi untuk Revisi UU Mahkamah Konstitusi, Jakarta: KRHN-USAID-DRSP, 2008.

Muchammad Ali Safa'at, dkk, Hukum Acara Mahkamah Konstitusi, Jakarta: Sekretariat Jenderal Mahkamah Konstitusi RI, 2011.

Peter Mahmud Marzuki, Penelitian Hukum, Jakarta: Prenadamedia, 2011.

Rita Triana Budiarti, Kontroversi Mahfud MD Jilid 1, Jakarta: Konstitusi Press, 2012.

---------, Kontroversi Mahfud MD Jilid 2 di Balik Putusan Mahkamah Konstitusi, Jakarta: Konstitusi Press, 2013.

Soerjono Soekanto dan Sri Mamudji, Penelitian Hukum Normatif; Suatu Tinjauan Singkat, Jakarta: Raja Grafindo Persada, 2009.

Soimin dan Mashuriyanto, Mahkamah Konstitusi dalam Sistem Ketatanegaraan Indonesia, Yogyakarta: UII Press, 2013.

Tim KRHN, Pokok-Pokok Pikiran dan RUU Mahkamah Konstitusi, Jakarta: KRHN dan Kemitraan, 2003.

Tim Penyusun, Hukum Acara Mahkamah Konstitusi, Jakarta: Sekretariat Jenderal dan Kepaniteraan MKRI, 2010.

\section{Makalah dan Jurnal}

Ali Marwan Hsb, "Mahkamah Konstitusi sebagai Neutralizer terhadap Lembaga Politik", Jurnal Rechtsvinding, Volume 2 Nomor 3, Desember 2013.

Mira Fajriyah, "Refraksi dan Alinasi Pengangkatan Hakim Konstitusi”, Jurnal Konstitusi, Volume 12, Nomor 2, Juni 2015.
Pan Mohamad Faiz, "Mekanisme Seleksi Hakim Konstitusi”, Koran Sindo, Kamis, 2 Februari 2017.

Shanti Dwi Kartika, "Seleksi untuk Pengangkatan Hakim Konstitusi”, Majalah Info Singkat Hukum, Vol. IX, No. 06/II/Puslit/Maret/2017.

\section{Peraturan Perundang-undangan}

Undang-Undang Dasar Negara Republik Indonesia Tahun 1945.

Undang-Undang Nomor 24 Tahun 2003 tentang Mahkamah Konstitusi.

Undang-Undang Nomor 8 Tahun 2011 tentang Perubahan atas Undang-Undang Nomor 24 Tahun 2003 tentang Mahkamah Kontitusi.

Peraturan Mahkamah Konstitusi Nomor 3 Tahun 2012 tentang Tata Cara Pemilihan Ketua dan Wakil Ketua Mahkamah Konstitusi.

\section{Website}

Bagus Joko Puruitomo dan Fitra Arsil, "Mekanisme Pengangkatan Hakim Konstitusi”, Makalah, hlm. 8 - 9, http://lib.ui.ac.id/ naskahringkas/2016-05/S55607-Bagus\%20 Joko\%20Puruitomo, diunduh pada 21 Februari 2018 Pukul 09.00 WIB.

h t t p:// nasion a $1 . \mathrm{kompas}$. com / $\mathrm{read} / 2017 / 12 / 14 / 18233891 / \mathrm{mk}-k a b u l k a n-$ penarikan-permohonan-uji-materi-terkait-hakangket-kpk, diakses pada 13 Februari 2018, Pukul 10.00 WIB.

https:// news.detik.com/berita/3864092/icwselama-ketua-mk-masih-arief-hidayat-kamitak-akan-gugat-uu-md3, diakses pada 13 Februari 2018, Pukul 10.10 WIB.

https://www.jpnn.com/news/hamdan-tolak-ikutfit-and-proper-test, diakses pada 21 Februari 2018, Pukul 10.00 WIB.

Jimly Asshiddiqie, "Kedudukan Mahkamah Konstitusi dalam Struktur Ketatanegaraan Indonesia",http: / www.mahkamahkonstitusi. go.id $/$ index.php?page=web.Berita\&id=11779\# . WoMMW7x19dI, diakses pada 14 Februari 2018, Pukul 09.00 WIB. 